\section{Regeneration of Abies pinsapo within gaps created by Heterobasidion annosum- induced tree mortality in southern Spain}

\author{
Rafael M Navarro-Cerrillo ${ }^{(1)}$, J Julio Camarero ${ }^{(2)}$, Rubén D Manzanedo ${ }^{(1)}$, \\ Rafael Sánchez-Cuesta ${ }^{(1)}$, José Lopez Quintanilla ${ }^{(3)}$, Raúl Sánchez \\ Salguero ${ }^{(1)}$
}

We explored the effects of tree-fall gaps caused by Heterobasidion annosum-induced tree death on the regeneration of the relict Abies pinsapo in southern Spain. We analyzed the structure and regeneration of $A$. pinsapo in 44 circular closed-canopy plots and 11 gaps (mean size $75 \mathrm{~m}^{2}$ ) located in $\mathrm{H}$. annosum infection foci. We measured adult density, basal area, and height of all tree species with a diameter at breast height greater than $7.5 \mathrm{~cm}$ and quantified regeneration abundance. Diameter structures were analyzed using Weibull functions. $A$. pinsapo comprised $49-81 \%$ of total adult tree density (358-1418 trees ha-1) and total basal area (15.70-39.22 $\left.\mathrm{m}^{2} \mathrm{ha}^{-1}\right)$. Density of $A$. pinsapo juveniles ranged from 129 to 416 individuals ha-1, while that of juveniles of other tree species such as Quercus ilex was much lower. $A$. pinsapo saplings and seedlings were more abundant within gaps than in closed-canopy sites. A. pinsapo regeneration was related to the tree species composition of the stands adjacent to gaps. The main potential species replacing $A$. pinsapo in $H$. annosum-induced gaps were, in decreasing order of importance, Quercus ilex, $Q$. faginea, and Juniperus oxycedrus. The current stand structure and gap-infilling processes suggest that $A$. pinsapo regenerates adequately within $H$. annosum-induced gaps. However, the relative proportion of other coexisting tree species within $H$. annosum-related gaps will increase substantially over time as compared with closed-canopy areas.

Keywords: Abies pinsapo, Mediterranean Forests, Forest Management, Gaps, Regeneration

\section{Introduction}

Comprehensive knowledge of how forest structure develops in response to natural disturbances is essential to evaluate current forest conditions and to promote sustainable silviculture and conservation systems in the future (McCarthy 2001). In Mediterranean montane forests, disturbances killing or removing small groups of trees are important drivers that create habitat heterogeneity and trigger successional dynamics (Dubé et al. 2005, Linares \& Carreira 2009). This pro-

cess may culminate in the replacement of the original dominant canopy species by individuals of different tree species at the stand scale. In such cases, gap disturbance would promotes the coexistence of species with different resource-use strategies, dispersal and competitive abilities (Veblen 1992). Implementation and exploitation of these natural succession processes in forest management is a desirable approach for threatened or endangered tree species. Therefore, detailed knowledge of how various tree species esta-

(1) Dept. Ingeniería Forestal, DendrodatLab, Universidad de Córdoba, Campus de Rabanales, Ctra. IV km. 396, E-14071 Cordoba (Spain); (2) ARAID, Instituto Pirenaico de Ecología (CSIC), Avda. Montañana 1005, E-50080 Zaragoza (Spain); (3) Consejería de Medio Ambiente, Junta de Andalucia, Sevilla (Spain)

@ Rafael M Navarro-Cerrillo (rmnavarro@uco.es)

Received: Jan 31, 2013 - Accepted: Nov 18, 2013

Citation: Navarro-Cerrillo RM, Camarero JJ, Manzanedo RD, Sánchez-Cuesta R, Lopez Quintanilla J, Sánchez Salguero R, 2014. Regeneration of Abies pinsapo within gaps created by Heterobasidion annosum-induced tree mortality in southern Spain. iForest 7: 209-215 [online 2014-02-27] URL: http://www.sisef.it/iforest/contents/?id=ifor0961-007

Communicated by: Renzo Motta blish within gaps could be an efficient way to introduce ecological mechanisms into current silvicultural systems (Veblen 1992, Beckage et al. 2000).

The Spanish fir (Abies pinsapo Boiss.) is a relict fir species endemic to southern Spain and northern Morocco. It has been hypothesized that $A$. pinsapo populations remained isolated throughout the Quaternary (AlbaSánchez et al. 2010). Such historical isolation caused significant morphological, genetic and ecological differentiation from other circum-Mediterranean fir species (Martín et al. 2010, Linares 2011). A. pinsapo forests were subjected to intense human use (e.g., grazing and logging for timber, firewood, and charcoal) until the mid- $20^{\text {th }}$ century. As a result, the current structure and tree species composition of $A$. pinsapo forests reflect their past use and management (Linares et al. 2010a, Esteban et al. 2010). Previous research on A. pinsapo regeneration has mainly focused on several reproductive stages of the species such as cone and seed production as well as seedling abundance (Arista et al. 1997). Nevertheless, there is scarce information on A pinsapo seedling and sapling abundance as related to gap dynamics.

Many studies on the role of gap formation in tree regeneration have been conducted in montane or temperate forests (Runkle 1985, Degen et al. 2005, Sapkota \& Odén 2009). However, little attention has been paid to the role of gaps as regeneration foci in Mediterranean conifer forests. Most studies on forest gap regeneration in mesic fir forests have been performed in continuous forests with large tree-fall gaps that greatly differ in size (Dobrowolska \& Veblen 2008). Yet, few studies have addressed how pest-related canopy gaps drive regeneration dynamics in Mediterranean fir forests. At the landscape scale, the natural disturbance regime of $A$. pinsapo forests in Spain is driven by fire, drought and fungal infection (Arista 1995, Linares \& Carreira 2009). In the absence of fire or pest outbreaks, the creation of small canopy gaps due to senescence and natural tree mortality is a common type of disturbance in formerly managed $A$. pinsapo forests. The establishment and survival of $A$. pinsapo seedlings within and outside these gaps is influenced by site conditions and stand species composition (Arista \& Talavera 1994, 1996). The incidence of fungal-related mortality induced by the root rot fungus Heterobasidion annosum Bref. (Basidiomyceta, Corialaceae) and to a lower extent by damage caused by other species (e.g., $A r$ millaria mellea (Vahl) P. Kumm) has increased over the last twenty years in formerly managed $A$. pinsapo forests (Navarro Cerrillo et al. 2003, Sánchez et al. 2007). In fact, significant differences in infection incidence of $H$. annosum have been observed 
between pure stands and mixed conifer stands (Swedjemark \& Stenlid 1995). A. pinsapo seedlings and saplings seem to be very susceptible to $H$. annosum, although no external differences between infected and healthy plants are visible. Moreover, drought stress affects the predisposition of $A$. pinsapo to $H$. annosum infection (Sánchez et al 2007).

The creation of gaps by $H$. annosum-induced tree death may promote the displacement of $A$. pinsapo by coexisting dominant tree species (Quercus ilex L., Pinus spp., and Quercus faginea Lam.). The regeneration of $A$. pinsapo often remains suppressed as a seedling bank under the closed canopy until an opening in the overstory allows seedling development (Arista 1995, Arista \& Talavera 1996). For instance, A. pinsapo regenerates well under the canopy of pine species $(P$. pinaster Aiton, $P$. halepensis Mill.) but recruits less successfully under the canopy of oak species $(Q$. faginea, $Q$. ilex) or in closed stands dominated by mature A. pinsapo trees. In addition, the micro-environmenta conditions of gaps seem to favor the establishment of $A$. pinsapo seedlings since seedling mortality in open areas (where seeds also germinate) is high due to summer drought stress (Arista et al. 1997). Understanding how the regeneration of $A$. pinsapo is driven by $H$. annosum-related gaps may contribute to better forecast stand-to-stand variation in tree species composition in these Mediterranean forests. This type of ecological knowledge is necessary for developing new silvicultural strategies to manage relict A. pinsapo forests.

We expected the composition and regeneration of mixed stands of $A$. pinsapo to differ between $H$. annosum-created gaps and adjacent closed-canopy stands. We hypothesized that gaps and adjacent closed-canopy stands would differ in several variables related to tree regeneration (i.e., density, structure, and composition). Finally, we examined the relationship between gap size and regeneration abundance as well as potential successor species (sensu Runkle 1985) within gaps to predict future forest composition.

\section{Material and methods}

\section{Study area}

The study sites were located in Sierra de las Nieves Natural Park (Malaga, Andalusia, Spain: $\left.36^{\circ} 43^{\prime} \mathrm{N}, 4^{\circ} 58^{\prime} \mathrm{W}\right)$. The area consists of a long, northbound ridge ranging in elevation from 1126 to $1562 \mathrm{~m}$. a.s.l. where A. pinsapo mainly occurs in wet or mesic sites. These forests are subjected to water deficit from June to September, a typical feature of Mediterranean climate. Average annual precipitation in the area is $1089 \mathrm{~mm}$ and mean annual temperature is $11.6{ }^{\circ} \mathrm{C}$. Soils are predominantly calcareous brown.
Most formerly pure $A$. pinsapo forests were converted by long-term human use to mixed forests with evergreen and deciduous oak species $(Q$. ilex and $Q$. faginea, respectively), also including natural and planted pine species ( $P$. halepensis, $P$. pinaster). Evidence of direct pest damage on $A$. pinsapo included bark beetle attack by Cryphalus numidicus Eichhoff (Coleoptera, Scolytidae) and fungal infection by $H$. annosum, creating all the sampled gaps.

\section{Field sampling}

In the selected stand, we located all canopy gaps showing signs of recent disturbance due to damage by root rot fungus $H$. annosum (i.e., broken stems with fungal damage, affected stumps, fungal bodies). In January 2009 , after a preliminary reconnaissance of the study area, eleven $A$. pinsapo gaps were selected based on forest inventories developed in 1999 by the regional Environment Department of Andalusia (Navarro Cerrillo et al. 2003). Gaps were selected according to the following criteria: (1) homogeneous soil and slope conditions within the gap; and (2) availability of information about the year of gap creation: we selected gaps created between 1995 and 1999. Although gap age was not accurately determined, relative age was estimated based on the condition of decaying logs and snags and previous inventory data. The center of the gap was marked as the point of intersection of its two dominant axes, and the area was estimated by measuring its long and short axes and assuming an elliptical shape. Gap size ranged from 502 to $1359 \mathrm{~m}^{2}$ and mean size was 673 $\mathrm{m}^{2}$. We established eleven northward-oriented sampling plots, one within each gap according to gap surface (plots had variable radii). To compare species, structure, and regeneration densities in gaps vs. closed-canopy sites, forty-four additional circular plots were randomly established at least $100 \mathrm{~m}$ apart from the closest gap border following $\mathrm{N}-\mathrm{S}-\mathrm{E}-\mathrm{W}$ directions. Each plot outside the gap had an area of $706.86 \mathrm{~m}^{2}$. We measured tree diameter at breast height (dbh) and height (using a hypsometer) and identified the tree species of all individuals with $\mathrm{dbh} \geq$ $2.5 \mathrm{~cm}$ located within gaps and closed-canopy plots. A. pinsapo individuals were grouped into four size classes according to their dbh and height: adults $(\mathrm{dbh} \geq 7.5 \mathrm{~cm})$; juveniles $(7.5 \mathrm{~cm}>\mathrm{dbh} \geq 2.5 \mathrm{~cm})$; saplings $(\mathrm{dbh}<2.5 \mathrm{~cm})$; and seedlings (height $<1.3$ $\mathrm{m})$. No differences were detected between gaps and adjacent closed-canopy stands in altitude, slope, orientation or soil type, supporting the assumption of site homogeneity. Spatial autocorrelations and the combined effects of pairs of gaps and closed-canopy plots were avoided by maintaining a minimum distance of $100 \mathrm{~m}$ between gaps and neighboring closed-canopy stands.

\section{Diameter structure analyses}

We grouped $A$. pinsapo, $Q$. ilex, $Q$. faginea, J. oxycedrus Sibth. \& Sm., and $J$. phoenicea $L$. into $5-\mathrm{cm}$ dbh classes, averaged densities across sampling plots, and generated diameter frequency distributions for each species at each site. To quantitatively compare population size structures, we fitted two-parameter Weibull functions (Kangas \& Maltamo 2000) using the SAS JMP ${ }^{\mathrm{TM}}$ statistical package and the maximum likelihood method.

\section{Statistical analyses}

Prior to the statistical analysis, we examined normal distribution of data and homogeneity of variances using the KolmogorovSmirnov and Levene tests, respectively. When departure from normality was detected, a log-transformation of data was applied. The parameters analyzed were tree density (trees ha $\left.{ }^{-1}\right)$, basal area $\left(\mathrm{m}^{2} \mathrm{ha}^{-1}\right)$, basal area of dead trees $\left(\mathrm{m}^{2} \mathrm{ha}^{-1}\right)$, quadratic mean diameter for all individuals with $\mathrm{dbh} \geq 2.5$ $\mathrm{cm}$, and regeneration (trees ha $\mathrm{a}^{-1}$ and saplings and seedlings with $\mathrm{dbh}<2.5 \mathrm{~cm}$ for all species).

Once fitting to a normal distribution and homogeneity of variances had been verified for all the variables analyzed, a simple paired $t$-Student test was applied in order to test for possible differences in structural variables and regeneration between gap and adjacent closed-canopy plots. A probability < 0.05 was accepted as statistical support for rejecting the null hypothesis (Zas 1999). We determined the relationships between the densities of juveniles, saplings and seedlings of the most abundant species in $H$. annosumcreated gaps and those of conspecific adults in adjacent closed canopy sites by calculating the Spearman's correlation coefficients $(\alpha=0.05$ - Zas 1999). Relationships between the structural and regeneration variables and gap size were assessed in a similar way. All the statistical analyses were carried out using the software package SPSS ver. 15 (SPSS Inc., Chicago, USA).

\section{Results}

\section{Stand structure}

Average density of trees with $\mathrm{dbh} \geq 7.5 \mathrm{~cm}$ in closed-canopy sites was 1749 trees ha $^{-1}$. Such sites were dominated by $A$. pinsapo, which comprised $81.2 \%$ of their total density, followed by P. halepensis (14.2\%), and J. oxycedrus $(4.0 \%$ - Tab. 1). In gaps, mean density was 723 trees ha ${ }^{-1}$. Again, A. pinsapo was dominant (49\%). Other significant tree species in gaps were $P$. halepensis $(26.6 \%)$, J. oxycedrus $(17.2 \%)$, Q. ilex (3.7\%), and Q. faginea $(2.2 \%)$.

As expected, the mean basal area of $A$. pinsapo (range: $15.7-39.2 \mathrm{~m}^{2} \mathrm{ha}^{-1}$ ) was significantly higher $(F=15.768 ; P<0.001)$ in clo- 
Tab. 1 - Structural parameters of Abies pinsapo populations in closed-canopy sites and Heterobasidion annosum-created gaps. Reported values are means (standard error in brackets). Significant differences between these two sites types (after $t$-test) are indicated. $(*): P \leq 0.05$; $(* *): P \leq 0.01 ;(\mathrm{ns})$ : not significant.

\begin{tabular}{|c|c|c|c|c|c|c|c|c|c|}
\hline \multirow[b]{2}{*}{ Site type } & \multirow[b]{2}{*}{ Species } & \multirow[b]{2}{*}{ 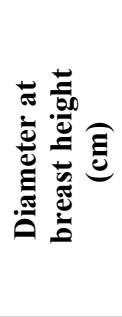 } & \multirow[b]{2}{*}{ 䒿葛 } & \multirow[b]{2}{*}{ 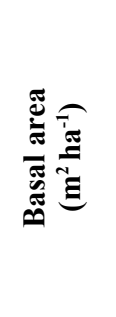 } & \multirow[b]{2}{*}{ 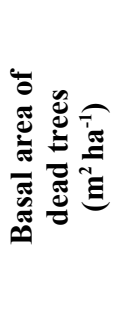 } & \multicolumn{4}{|c|}{ Density (trees ha ${ }^{-1}$ ) } \\
\hline & & & & & & 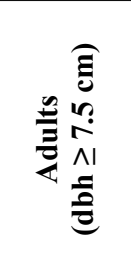 & 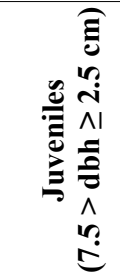 & 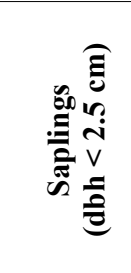 & 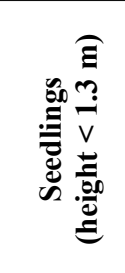 \\
\hline \multirow{9}{*}{$\begin{array}{l}\text { Closed-canopy } \\
\text { sites }\end{array}$} & Abies pinsapo & $19.88^{*}$ & $6.54^{\text {ns }}$ & $39.22^{\text {ns }}$ & 2.03 ** & $1418 * *$ & $129 * *$ & $317 * *$ & $1816 * *$ \\
\hline & Pinus halepensis & $\begin{array}{l}(0.89) \\
20.23^{\text {ns }}\end{array}$ & $\begin{array}{l}(0.16) \\
6.49^{\text {ns }}\end{array}$ & $\begin{array}{l}(1.87) \\
7.65^{\text {ns }}\end{array}$ & $\begin{array}{l}(1.87) \\
0.71^{\text {ns }}\end{array}$ & $\begin{array}{l}(32.16) \\
249^{\text {ns }}\end{array}$ & $\begin{array}{l}(6.21) \\
73^{\text {ns }}\end{array}$ & $\begin{array}{c}(9.21) \\
6^{\text {ns }}\end{array}$ & $\begin{array}{l}(43.56) \\
532^{\mathrm{ns}}\end{array}$ \\
\hline & & $(3.15)$ & $(0.64)$ & $(0.69)$ & $(0.09)$ & $(7.24)$ & $(2.45)$ & $(1.21)$ & $(14.70)$ \\
\hline & Quercus ilex & $6.63^{* *}$ & $1.72 * *$ & $0.67^{*}$ & - & $5^{* *}$ & $86^{*}$ & $179 * *$ & $312^{* *}$ \\
\hline & & $(0.66)$ & $(0.48)$ & $(0.05)$ & & $(0.30)$ & $(5.41)$ & $(11.61)$ & $(19.21)$ \\
\hline & Quercus faginea & $\begin{array}{l}24.31 \text { ** } \\
(3.12)\end{array}$ & $\begin{array}{l}3.95^{* *} \\
(0.93)\end{array}$ & $0.27 * *$ & - & $4^{*}$ & - & - & - \\
\hline & Juniperus oxycedrus & $9.15^{* *}$ & $1.86^{* *}$ & $2.58^{* *}$ & - & $70^{* *}$ & $9^{\mathrm{ns}}$ & $56^{* *}$ & $116^{* *}$ \\
\hline & & $(0.28)$ & $(0.17)$ & $(0.01)$ & & $(5.12)$ & $(1.01)$ & $(7.12)$ & $(23.02)$ \\
\hline & Juniperus phoenicea & $\begin{array}{l}8.06^{\text {ns }} \\
(1.27)\end{array}$ & $\begin{array}{l}1.43^{*} \\
(0.15)\end{array}$ & $\begin{array}{l}0.26^{\text {ns }} \\
(0.03)\end{array}$ & - & $\begin{array}{l}3^{\mathrm{ns}} \\
(1.00)\end{array}$ & $\begin{array}{l}12^{\mathrm{ns}} \\
(3.09)\end{array}$ & $\begin{array}{l}37^{\mathrm{ns}} \\
(5.45)\end{array}$ & $\begin{array}{l}71^{*} \\
(12.98)\end{array}$ \\
\hline \multirow[t]{6}{*}{ Gaps } & Abies pinsapo & $\begin{array}{l}11.60 \\
(1.18)\end{array}$ & $\begin{array}{l}5.07 \\
(0.45)\end{array}$ & $\begin{array}{l}15.7 \\
(1.55)\end{array}$ & $\begin{array}{c}6.43 \\
(1.55)\end{array}$ & $\begin{array}{l}358 \\
(45.23)\end{array}$ & $\begin{array}{l}416 \\
(20.12)\end{array}$ & $\begin{array}{l}1135 \\
(43.78)\end{array}$ & $\begin{array}{l}2145 \\
(72.23)\end{array}$ \\
\hline & Pinus halepensis & $\begin{array}{l}19.79 \\
(2.36)\end{array}$ & $\begin{array}{l}6.23 \\
(0.14)\end{array}$ & $\begin{array}{l}7.41 \\
(0.73)\end{array}$ & $\begin{array}{c}0.93 \\
(0.08)\end{array}$ & $\begin{array}{l}193 \\
(3.93)\end{array}$ & $\begin{array}{l}25 \\
(7.03)\end{array}$ & $\begin{array}{l}619 \\
(16.99)\end{array}$ & $\begin{array}{l}3417 \\
(114.67)\end{array}$ \\
\hline & Quercus ilex & $\begin{array}{c}8.31 \\
(1.01)\end{array}$ & $\begin{array}{l}2.8 \\
(0.55)\end{array}$ & $\begin{array}{l}1.41 \\
(0.03)\end{array}$ & - & $\begin{array}{l}27 \\
(4.41)\end{array}$ & $\begin{array}{l}97 \\
(6.39)\end{array}$ & $\begin{array}{l}216 \\
(18.11)\end{array}$ & $\begin{array}{c}1719 \\
(18.08)\end{array}$ \\
\hline & Quercus faginea & $\begin{array}{c}9.25 \\
(2.63)\end{array}$ & $\begin{array}{l}2.6 \\
(0.30)\end{array}$ & $\begin{array}{c}0.69 \\
(0.02)\end{array}$ & - & $\begin{array}{l}16 \\
(1.93)\end{array}$ & $\begin{array}{l}37 \\
(4.43)\end{array}$ & $\begin{array}{l}114 \\
(11.06)\end{array}$ & $\begin{array}{l}854 \\
(30.12)\end{array}$ \\
\hline & Juniperus oxycedrus & $\begin{array}{l}10.45 \\
(1.54)\end{array}$ & $\begin{array}{l}2.32 \\
(0.34)\end{array}$ & $\begin{array}{c}3.52 \\
(0.09)\end{array}$ & - & $\begin{array}{l}125 \\
(18.08)\end{array}$ & $\begin{array}{l}205 \\
(26.06)\end{array}$ & $\begin{array}{l}381 \\
(23.78)\end{array}$ & $\begin{array}{l}1062 \\
(43.14)\end{array}$ \\
\hline & Juniperus phoenicea & $\begin{array}{l}10.33 \\
(1.71)\end{array}$ & $\begin{array}{l}1.85 \\
(0.22)\end{array}$ & $\begin{array}{c}0.19 \\
(0.04)\end{array}$ & - & $\begin{array}{l}4 \\
(2.71)\end{array}$ & $\begin{array}{l}14 \\
(6.94)\end{array}$ & $\begin{array}{l}49 \\
(12.87)\end{array}$ & $\begin{array}{l}216 \\
(23.69)\end{array}$ \\
\hline
\end{tabular}

sed-canopy sites than in gaps (Tab. 1). The basal area of standing dead trees and fallen dead trees averaged $6.4 \mathrm{~m}^{2} \mathrm{ha}^{-1}$ in gaps and $2.0 \mathrm{~m}^{2} \mathrm{ha}^{-1}$ in closed-canopy areas, showing significant differences $(F=14.521 ; P<$ $0.001)$. In gaps, the quadratic mean diameter of $A$. pinsapo was $11.6 \mathrm{~cm}$, significantly smaller than in closed-canopy sites $(F=$ 7.135; $P=0.010)$, as it was also the case for $Q$. faginea $(F=34.639 ; P<0.001)$. However, other species showed the opposite pattern, with significantly higher quadratic mean diameters within than outside gaps. This was the case of $Q$. ilex $(F=23.575 ; P<$ $0.001)$ and $J$. oxycedrus $(F=22.886 ; P<$ $0.001)$. We found differences in the mean height of trees located within gaps and in closed-canopy sites in all tree species except $Q$. faginea. Several tree species showed significantly lower height when growing in closed-canopy sites than within gaps $(J$. phoenicea, $F=15.780 ; P<0.001 ; J$. oxycedrus, $F=56.877 ; P<0.001 ; Q$. ilex, $F=$ 23.575; $P<0.001$; see Tab. 1).

Diameter $(\mathrm{dbh} \geq 2.5 \mathrm{~cm})$ distributions varied between site types but tended to be regular among diameter classes (Fig. 1). The shape of the size-class Weibull distribution showed significant differences between an exponential distribution in gaps $(c=1.0$; $P<0.001)$ and a positively skewed Weibull distribution in closed-canopy sites $(c=1.56)$. The exponential distributions were the result of a peak in abundance in the smallest and intermediate size classes, and a rapid decline in the number of individuals in larger size classes (Fig. 1). This indicates that A. pinsapo regeneration within gaps was abundant. The number of small diameter trees (dbh between $2.5-7.5 \mathrm{~cm}$ ) was up to three times greater in gaps than in closed-canopy sites (Fig. 1, Tab. 1). In both site types, few large trees $(\mathrm{dbh} \geq 40 \mathrm{~cm})$ existed; the remaining species had relatively low density and diameter, and distributions were generally leftskewed $(c>2.90)$ on average and dominated by a large number of small diameter trees, suggesting an active regeneration of coexisting tree species (Fig. 1, Tab. 1).

\section{Regeneration abundance}

Density of $A$. pinsapo juveniles was significantly higher in gaps (416 trees ha $\left.\mathrm{h}^{-1}\right)$ than in closed-canopy stands $(F=10.633 ; P<$
0.001 - Tab. 1). Density of $A$. pinsapo saplings and seedlings also differed significantly $(P<0.001)$ between sites types. More specifically, density of $A$. pinsapo saplings was over three times greater within gaps than elsewhere (Tab. 1).

Density of $Q$. ilex juveniles ranged from 97 to 86 trees $\mathrm{ha}^{-1}$. It was significantly higher in gaps $(F=10.963 ; P=0.002)$ than in closedcanopy sites. Moreover, the highest numbers of saplings and seedlings of this species occurred in stands with the lowest density of A. pinsapo adults. A clear influence of gaps on tree regeneration was observed in $Q$. $f a$ ginea, which was only present in gaps (Tab. 1). Significant differences between site types in the average numbers of recruits were also found in Juniperus species (Tab. 1).

\section{Relationship between gap size and} forest structure and regeneration

A significant positive correlation was found between gap size and the density and basal area of $A$. pinsapo, $Q$. faginea, and $Q$. ilex (Tab. 2). In addition, gap area was negatively correlated with the average basal area of $P$. halepensis and Juniperus species, 
Gap of $H$. annosum Abies pinsapo forests

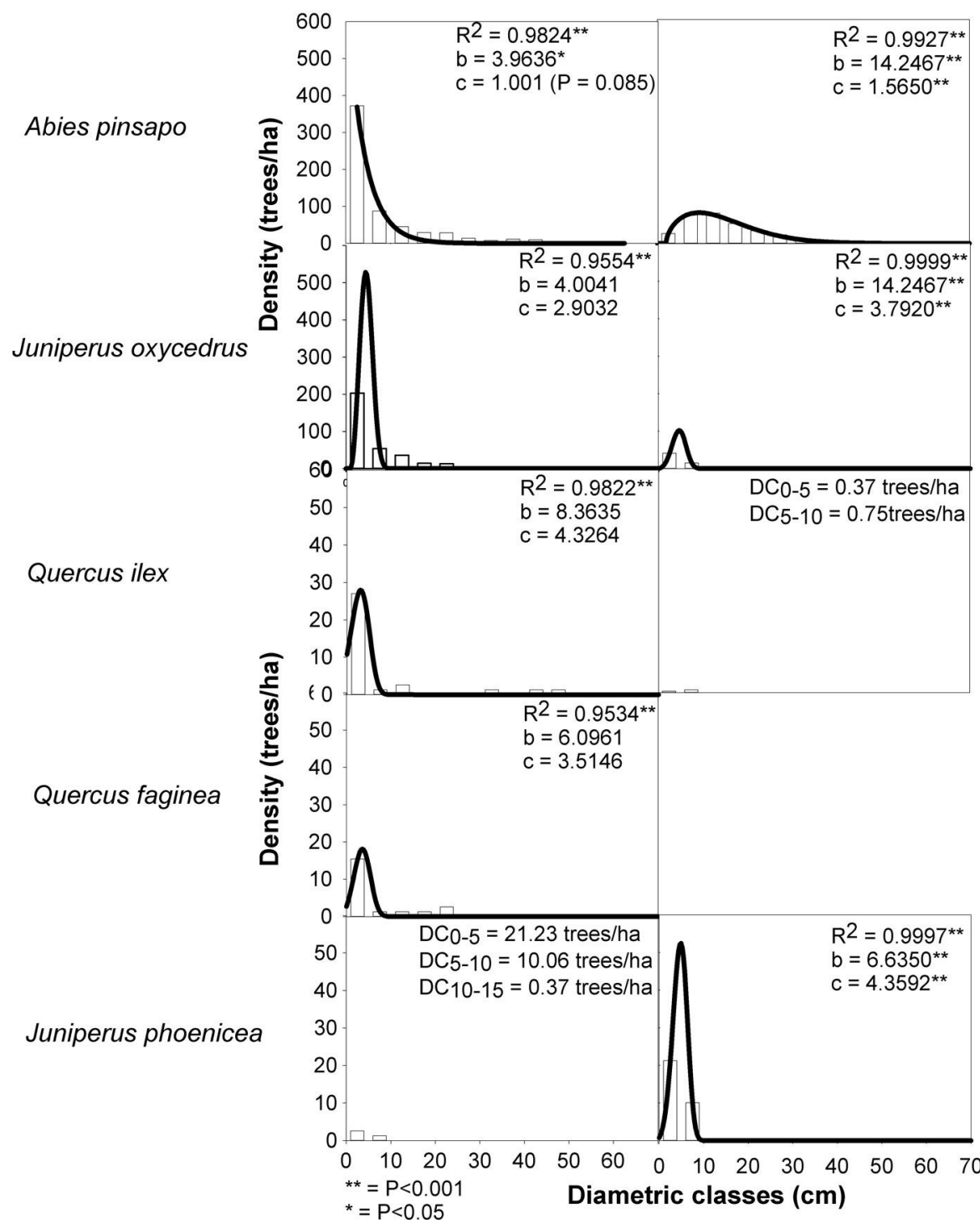

Tab. 2 - Spearman's correlation matrix among gap size forest variables and regeneration. $(*): P<0.05 ;$ (a): $\Sigma$ juveniles + saplings + seedlings.

\begin{tabular}{lccc}
\hline Species & $\begin{array}{c}\text { Density } \\
(\text { trees ha }\end{array}$ & $\begin{array}{c}\text { Basal area } \\
\left(\mathbf{m}^{\mathbf{2}} \mathbf{h a}^{-\mathbf{1}} \mathbf{)}\right.\end{array}$ & $\begin{array}{c}\text { Regeneration } \\
\text { (trees ha }^{-1} \mathbf{)}\end{array}$ \\
\hline Abies pinsapo & $0.748^{*}$ & $0.83^{*}$ & 0.276 \\
Pinus halepensis & 0.029 & -0.057 & -0.216 \\
Quercus ilex & $0.873^{*}$ & $0.8^{*}$ & 0.095 \\
Quercus faginea & $0.924^{*}$ & $0.768^{*}$ & -0.132 \\
Juniperus oxycedrus & -0.227 & -0.228 & -0.293 \\
Juniperus phoenicea & -0.041 & -0.043 & 0.142 \\
\hline
\end{tabular}

Tab. 3 - Relationships between densities of juveniles, saplings, and seedlings of the most abundant species located within Heterobasidion annosum-created gaps and densities of conspecific adults located in surrounding closed-canopy sites. Values are Spearman's correlation coefficients. $(*): P \leq 0.05 ;(* *): P \leq 0.01$.

\begin{tabular}{lcccc}
\hline Stage & A. pinsapo & P. halepensis & Q. ilex & J. oxycedrus \\
\hline Juveniles & $0.25^{*}$ & $0.27^{*}$ & $0.3^{*}$ & 0.08 \\
Saplings & $0.38^{* *}$ & $0.28^{*}$ & $0.34^{*}$ & 0.04 \\
Seedlings & $0.5^{* *}$ & $0.4^{* *}$ & $0.77^{* *}$ & 0.04 \\
\hline
\end{tabular}

Fig. 1 - Frequencies of trees grouped according to their diameters at breast height (dbh, 5 -cm classes) for the different species sampled and corresponding Weibull distributions (solid lines) for gaps and closed-canopy sites in an $A$. pinsapo forest. Fitting parametrs (Rsquared) and Weibull shape statistics $(b, c)$ are also indicated. Where fittting was not possible, densities of each class are shown. although the latter correlation was not significant. By contrast, their regeneration was not related to gap size.

\section{Potential successors}

Significant correlations were found between: (1) density of juveniles, saplings, and seedlings of $A$. pinsapo, $P$. halepensis and Q. ilex; and (2) abundance of such species in surrounding closed-canopy sites (Tab. 3). The highest coefficients were found for seedlings of these three species. In gaps, the main potential successor was $A$. pinsapo, representing $50 \%$ of the total density of recruits. However, $Q$. ilex and $J$. oxycedrus were other potential successors that occurred more frequently within gaps than expected compared to their abundance within closed-canopy stands. 


\section{Discussion}

The regeneration dynamics of $A$. pinsapo forests and the implications of ecological factors and silvicultural practices on their recruitment patterns still remain an open research topic. This study showed that $A$. pinsapo is able to establish in gaps created after $H$. annosum-induced tree death. Our results also showed a significant difference between gaps and adjacent closed-canopy stands in forest structure and regeneration dynamics Nevertheless, there is much debate over the level of perturbation that is necessary to maintain $A$. pinsapo populations in forests and the mechanisms involved (Linares et al 2010a). The current structure of $A$. pinsapo forests is the result of decades of timber harvesting, fire, and livestock overgrazing, followed by a lack of forest management practices over the last twenty years (Esteban et al. 2010). However, H. annosum-induced gaps have appeared in recent years as a relatively sharp disruption of forest dynamics. Fungal infection seems to play an important role in providing opportunities for tree regeneration of other key tree species, as reported for other fir species in mesic areas (Yamamoto 2000, Dobrowolska \& Veblen 2008).

Tree density and basal area values of $A$. pinsapo in the study area were comparable to those reported in the literature, with densities (basal areas) ranging between 1418 $\left(39.22 \mathrm{~m}^{2} \mathrm{ha}^{-1}\right)$ and 358 trees ha ${ }^{-1}\left(15.70 \mathrm{~m}^{2}\right.$ $\mathrm{ha}^{-1}$ ) in closed-canopy sites and gaps, respectively. Comparatively, Linares et al (2010a) estimated density and basal area values of $A$. pinsapo to be within the intervals 1314-2535 trees $\mathrm{ha}^{-1}$ and 37.64-46.93 $\mathrm{m}^{2}$ $\mathrm{ha}^{-1}$, respectively. Our results show slightly lower average densities than those reported above. We attribute this to the larger number of plots examined and diameter classes used in this study. Species composition remained similar when we compared closed-canopy sites with neighboring gaps. However, gaps showed an increase in density and basal area of more shade-tolerant species such as the oaks $Q$. ilex and $Q$. faginea. Similar compositional changes have been documented for A. pinsapo-dominated stands in moist and high-elevation sites in the same location (Navarro Cerrillo et al. 2011). Gap size is influenced by various factors such as the number, causes, and sizes of tree falls (Abe et al. 1995). We found a significant positive correlation between gap size and density and basal area of dominant tree species (i.e., A. pinsapo, $Q$. faginea and $Q$. ilex) that is consistent with the ecological features of these species (Arista 1995, Rodá et al. 1999, Esteso-Martínez et al. 2006).

Tree structure is also important to determine the effects of gap creation on tree composition and dynamics. The Weibull shape parameters reported for A. pinsapo showed an exponential distribution in gaps and a positively skewed distribution in closed-canopy sites. This indicates the existence of abundant young individuals and very good regeneration status, particularly within gaps (Linares \& Carreira 2009, Linares et al. $2010 \mathrm{~b}, 2011 \mathrm{~b})$. The forest structure of $A$. pinsapo forests resembles that of uneven-age or multicohort-disturbed forests, whose regeneration comes in pulses when favorable climatic conditions occur or when regeneration sites and prolific seed crops are available (Oliver \& Larson 1996).

Densities of $A$. pinsapo seedlings and saplings found in gaps were similar or greater than those reported by Arista (1995). In general, all the study areas showed high seedling and sapling densities, which may reflect the ability of $A$. pinsapo to recruit quickly in disturbed forests due to a high seed input from surviving trees. A. pinsapo seedlings appear in large numbers after years of abundant cone production, which occur at approximately 3-year intervals (Arista 1995). Abundance of seedlings and saplings suggests that $A$. pinsapo is currently regenerating successfully in relict populations in southern Spain (Tab. 1, Fig. 1). Since sapling and juvenile densities were high, $A$. pinsapo establishment does not appear to be a problem in these stands. Instead, we observed a bottleneck in recruitment between seedling and sapling stage that has also been pointed out by previous researchers (Arista 1995, Arista et al. 1997). Seedlings appear to be suppressed and do not move into larger size-classes. This is related to stand development, including high mortality or suppression of seedlings and saplings (Arista \& Talavera 1994, 1996). Under some circumstances, the drought-tolerant $P$. halepensis may fill the gap and form the canopy of the future stand. However, the abundance of this species as recruits was low, which is consistent with its scarcity in closed-canopy stands (14\% of the total density). Density of seedlings and saplings of $Q$. ilex, $J$. oxycedrus, and $J$. phoenica was also higher in gaps than in closed-canopy sites. These species are relatively shade-tolerant and their abundance appears to be more limited by suitable light conditions in gaps than by the proximity of potential parent trees. For example, regeneration of $Q$. faginea only occurred within gaps. However, the number of saplings and seedlings of $Q$. ilex was significantly greater in gaps than outside. The density of saplings of all species was lower than that of seedlings in gaps, probably because of increasing competition and mortality rates among neighboring recruits. Environmental factors such as light, temperature, air humidity, or soil moisture acting at small spatial scales are possible drivers of drought-induced mortality of A. pinsapo seedlings (Arista 1995). Gap size was not related to established re- generation, since larger gaps were not associated with higher presence of sapling and seedlings of any tree species. However, gaps seem to be sites of particular interest for the establishment of more shade-tolerant tree species. Our surveys have shown that $A$. pinsapo trees often remain alive for more than 10 years after gap creation. Consequently, an initial transformation of impacted areas to an overstory of this species takes place, along with $Q$. ilex, $Q$. faginea, $J$. oxycedrus, and $J$. phoenica. In the long run, many $A$. pinsapo trees will also die and leave openings in the forest canopy that will be dominated by those species. Given the susceptibility of $A$. pinsapo seedlings and saplings to $H$. annosum, this allows more time for $H$. annosum to occupy a large portion of the living root system and remain pathogenic for longer periods. We suggest that oak seedlings and saplings dominate $H$. annosum-created gaps. Additionally, frequency of shade-tolerant species such as $Q$. ilex and $Q$. faginea exhibited a strong relationship with gap size, which makes them potential competitors of A. pinsapo recruits (Linares et al. 2010b, Linares et al. 2011a).

Past management and recent conservation practices probably also influenced the current abundance values of $A$. pinsapo. For example, large $A$. pinsapo trees remained but many Quercus stands were logged and coppiced in the past (Esteban et al. 2010). Other explanations for the decrease of some species may include browsing by ungulates and the abundance of advanced regeneration of A. pinsapo, which can hinder the development of more light-demanding and pioneer conifer species such as $P$. halepensis and $J u$ niperus species. Mean height of $Q$. ilex trees growing under the closed canopy was lower than within gaps. $Q$. ilex is very plastic and may be able to survive in the understory and accelerate its growth in response to increased light levels, thus constituting a seedling bank of advance regeneration (Rodá et al. 1999).

Density of seedlings and saplings of $A$. pinsapo and $Q$. ilex in gaps was tightly correlated with the density of such species in surrounding closed-canopy stands. These are relatively shade-tolerant species that can occur in gaps and whose abundance appeared to depend on the presence of nearby parent trees. The main potential successor of $A$. pinsapo was $Q$. ilex. However, the abundance of juveniles of certain species does not necessarily imply that they will dominate as the stand develops. All potential successors are light-demanding species and grow slowly in the juvenile stages but can accelerate their growth rates under better light conditions leading to stronger competitive interactions with $A$. pinsapo trees as they age.

\section{Conclusions}

Evidence obtained in this study suggests 
that $A$. pinsapo regenerates after $H$. annosum-related gaps are formed in relict forests in southern Spain, which is also consistent with the diameter distributions presented. We found abundant adults and recruits of $Q$. ilex, $Q$. faginea, $P$. halepensis and Juniperus species in mixed $A$. pinsapo forests, where these species appear to be early successional species and potential candidates for replacing A. pinsapo. Regeneration of $Q$. faginea was only detected within gaps. However, the ability of these tree species to replace the long-living $A$. pinsapo in gaps cannot be easily predicted, and size and age structures can lag far behind those predicted from observed recruitment data. Changes from relatively closed-canopies to relatively more open forest structures have promoted major changes in the dynamics of mixed $A$. pinsapo forests. The vegetation patterns we found in the canopy gaps of $A$. pinsapo forests comprise a number of species that increases with gap size, a relatively homogenous species composition in gaps of various sizes, and an increasing proportion of generalist species as a result of a higher light availability in larger gaps. We found a significant positive correlation between gap size and the density and basal area of the dominant tree species $A$. pinsapo, $Q$. faginea and Q. ilex.

Warming-induced drought stress and enhanced $H$. annosum damage in $A$. pinsapo forests could foster the creation of more gaps and accelerate these successional dynamics. The information gleaned from this study will help to achieve a better understanding of the structure and management of mixed $A$. pinsapo forests.

\section{Acknowledgments}

This work was funded by the Regional Government of Andalusia and the project DIVERBOS (CGL2011-30285-C02-02). R. Sánchez-Salguero acknowledges a grant for the training of university teachers (FPU, AP2007-04747, Spanish Ministry of Education). We also acknowledge the financial support from the University of CordobaCampus de Excelencia. J. Julio Camarero wishes to thank ARAID for its support. We are also grateful to the regional Forest Department of Andalusia for allowing us to conduct field research in the Sierra de las Nieves Nature Park and the forest rangers for providing data and for their help in setting up the field inventory.

\section{References}

Abe S, Masaki T, Nakashizuka T (1995). Factors influencing sapling composition in canopy gaps of a temperate deciduous forest. Plant Ecology 120: 21-32

Alba-Sánchez F, López-Sáez JA, Benito-de Pando B, Linares JC, Nieto-Lugilde D, López-Merino L (2010). Past and present potential distribution of the Iberian Abies species: a phytogeographic approach using fossil pollen data and species distribution models. Diversity and Distribution 16: 214-228. - doi: 10.1111/j.1472-4642.2010.006 36.x

Arista M, Herrera FJ, Talavera S (1997). Biología del pinsapo. Consejería de Medio Ambiente, Sevilla, Spain. [in Spanish]

Arista M, Talavera S (1994). Phenology and anatomy of the reproductive phase of Abies pinsapo Boiss. (Pinaceae). Botanical Journal of the Linnean Society 116: 223-234. - doi: 10.1111/j.10 95-8339.1994.tb00431.x

Arista M, Talavera S (1996). Density effect on the fruit-set, seed crop viability and seedling vigour of Abies pinsapo. Annals of Botany 77: 187-192. - doi: 10.1006/anbo.1996.0021

Arista M (1995). The structure and dynamics of an Abies pinsapo forests in southern. Spain. Forest Ecology and Management 74: 81-89. doi: 10.1016/0378-1127(94)03507-S

Beckage B, Clark JS, Clinton BD, Haines BL (2000). A long-term study of tree seedling recruitment in southern Appalachian forests: the effects of canopy gaps and shrub understories. Canadian Journal of Forest Research 30: 16171631. - doi: 10.1139/x00-075

Degen T, Devillez F, Jacquemart AL (2005). Gaps promote plant diversity in beech forests (LuzuloFagetum), North Vosges, France. Annals of Forest Science 62: 429-440. - doi: 10.1051/fo rest:2005039

Dobrowolska D, Veblen TT (2008). Treefall-gap structure and regeneration in mixed Abies alba stands in central Poland. Forest Ecology and Management 255: 3469-3476. - doi: 10.1016/j.foreco.2008.02.025

Dubé P, Menard A, Bouchard A, Marceau DJ (2005). Simulating the impact of small-scale extrinsic disturbances over forest volumetric light environment. Ecological Modelling 182: 113129. - doi: 10.1016/j.ecolmodel.2004.04.030

Esteban L, de Palacios P, Rodríguez-Losada L (2010). Abies pinsapo forests in Spain and Morocco: threats and conservation. Oryx 44: 276284. - doi: 10.1017/S0030605310000190

Esteso-Martínez J, Camarero JJ, Gil-Pelegrín E (2006). Competitive effects of herbs on Quercus faginea seedlings inferred from vulnerability curves and spatial-pattern analyses in a Mediterranean stand (Iberian System, northeast Spain). Ecoscience 13: 378-387. - doi: 10.2980/i11956860-13-3-378.1

Kangas A, Maltamo M (2000). Performance of percentile based diameter distribution prediction and Weibull method in independent data sets. Silva Fennica 34: 381-398.

Linares JC (2011). Biogeography and evolution of Abies (Pinaceae) in the Mediterranean basin: the roles of long-term climatic change and glacial refugia. Journal of Biogeography 38: 619-630 doi: 10.1111/j.1365-2699.2010.02458.x

Linares JC, Carreira JA (2009). Temperate-like stand dynamics in relict Mediterranean-fir (Abies pinsapo Boiss.) forests from southern Spain. Annals of Forest Science 66: 610-620. - doi: 10.1051/forest/2009040

Linares JC, Camarero JJ, Carreira JA (2010a). Competition modulates the adaptation capacity of forests to climatic stress: insights from recent growth decline and death in relict stands of the Mediterranean fir Abies pinsapo. Journal of Ecology 98: 592-603. - doi: 10.1111/j.1365-2745.20 10.01645.x

Linares JC, Camarero JJ, Bowker MA, Ochoa V, Carreira JA (2010b). Stand-structural effects on Heterobasidion abietinum-related mortality following drought events in Abies pinsapo. Oecologia 164: 1107- 1119. - doi: 10.1007/s00442-0101770-6

Linares JC, Delgado-Huertas A, Carreira JA (2011a). Climatic trends and different drought adaptive capacity and vulnerability in a mixed Abies pinsapo - Pinus halepensis forest. Climatic Change 105: 67-90. - doi: 10.1007/s10584010-9878-6

Linares JC, Carreira JA, Ochoa V (2011b). Human impacts drive forest structure and diversity. Insights from Mediterranean mountain forest dominated by Abies pinsapo. European Journal of Forest Research 130: 533-542. - doi: 10.1007/ s10342-010-0441-9

Martín A, Alvarez JB, Martín L (2010). Genetic diversity of Spanish fir (Abies pinsapo Boiss.) populations by means of megagametophyte storage proteins. Annals of Forest Science 67: 603. - doi: 10.1051/forest/2010016

McCarthy J (2001). Gap dynamics of forest trees: a review with particular attention to boreal forests. Environmental Review 9: 1-59. - doi: 10 1139/a00-012

Navarro Cerrillo RM, Calzado C, Sánchez ME, López J, Trapero A (2003). Censo de focos de Heterobasidion annosum (Fr.) Bref. en ecosistemas de pinsapo [Census outbreaks of Heterobasidion annosum (Fr.) Bref. in A. pinsapo ecosystems]. Boletin de Sanidad Vegetal y Plagas 29: 581-92. [in Spanish]

Navarro Cerrillo RM, Guzmán Alvarez JR, LopézQuintanilla JL, Sánchez Salguero R, Moreno J, Sánchez G (2011). Restauración del pinsapo (Abies pinsapo Boiss.) en Andalucía. In: "Pinsapares de Andalucía” (López, J, Navarro-Cerrillo RM, Carreira J eds). Consejería de Medio Ambiente, Sevilla, Spain, pp. 152-187. [in Spanish]

Oliver CD, Larson BC (1996). Forest stand dynamics. John Wiley \& Sons, Inc., New York, USA, pp. 145.

Rodá F, Retana J, Gracia CA, Bellot J (1999). Ecology of Mediterranean evergreen oak forests. Ecological Series vol. 137, Springer, Berlin, Germany, pp. 373

Runkle JR (1985). Disturbance regimes in temperate forests. In: "The Ecology of Natural Disturbance and Patch Dynamics" (Pickett ST, White PS eds). Academic Press, Orlando, FL, USA, pp. 17-33.

Sánchez ME, Luchi N, Jiménez JJ, De Vita P, Sánchez JE, Trapero A, Capretti P (2007). An isolated population of Heterobasidion abietinum on Abies pinsapo in Spain. Forest Pathology 37: 348-356. - doi: 10.1111/j.1439-0329.2007.0051 
4. $\mathrm{x}$

Sapkota IP, Odén PC (2009). Gap characteristics and their effects on regeneration, dominance and early growth of woody species. Journal of Plant Ecology 2: 21-29. - doi: 10.1093/jpe/rtp004

Swedjemark G, Stenlid J (1995). Susceptibility of conifer and broadleaf seedlings to Swedish $\mathrm{S}$ and
$\mathrm{P}$ strains of Heterobasidion annosum. Plant Pathology 44: 73-79. - doi: 10.1111/j.1365-3059. 1995.tb02717.x

Veblen TT (1992). Regeneration dynamics. In: "Plant Succession: Theory and Prediction" (Glenn-Lewin D, Peet R eds). Chapman and Hall, London, UK, pp. 152-187.
Yamamoto S (2000). Forest gap dynamics and tree regeneration. Journal of Forest Research 5: 223-229. - doi: 10.1007/BF02767114

Zas JH (1999). Biostatical analysis (4th edn). Prentice Hall, Englewood Cliffs, USA. 